ANDREW TILKER (๑ orcid.org/0000-0003-3630-8691) Re:wild, Austin, USA, and Leibniz Institute for Zoo and Wildlife Research,Berlin, Germany.E-mail atilker@globalwildlife.org

This is an Open Access article, distributed under the terms of the Creative Commons Attribution licence CC BY 4.0.

\section{Preliminary survey of the southernmost Tapanuli orangutan population}

The newly discovered orangutan species Pongo tapanuliensis faces population declines driven by habitat fragmentation and hunting. Historically, the Tapanuli orangutan occurred from the uplands of West Toba lake in North Sumatra to the Bukit Tinggi district, West Sumatra, but the current population is limited to the Batang Toru ecosystem, North Sumatra, in three forest blocks separated by a river and roads. Most Tapanuli orangutan populations are in unprotected forest areas, although the southernmost population is in the Lubuk Raya Reserve.

With the support of Tropical Forest Conservation Action-Sumatra, we conducted a preliminary study of the Tapanuli orangutan in the Lubuk Raya Reserve in January 2021. In a $10 \mathrm{~km}$ transect survey we did not encounter any orangutan nests, although we observed three nests outside the targeted transect, and a habitat suitability analysis showed that $44 \%$ of the area could potentially be used by orangutans. We spoke with 20 people in seven villages and found that they see orangutans in this area, especially those people who live on the border of natural forests and agricultural lands. Most correspondents indicated they do not kill orangutans, although previous studies have found that hunting has caused drastic declines in Sumatran orangutan populations.

Although zero losses have been proposed as a means to save the Tapanuli orangutan (Oryx, 55, 10-11), other approaches are needed. More than half of the species' population occurs outside protected areas, and we observed extensive agricultural expansion in the area we surveyed, which could trigger conflict with orangutans. However, many local people are aware of the conservation status of this species as the result of an ongoing campaign by the orangutan conservation project of the United States Agency for International Development, which began in 2007. Any strategy to protect the Tapanuli orangutan will need to involve communities and the private sector, with collaborative management, and the establishment of a sanctuary for the species that could be used for ecotourism.

DidIK PRASETYo (@ orcid.org/0000-0001-5486-2624) Fakultas Biologi Universitas Nasional, Jakarta, Indonesia

E-mail dprasetyo.unas@gmail.com
MISDI MISDI Fakultas Pertanian prodi Kehutanan, Program Studi di Kampus Utama Universitas Syiah Kuala Gayolues, Jalan Blangkejeren-Blangpidie, Aceh, Indonesia

Taufik Mulyana, Fauzan Cholifatullah and HAERUDIN SADJUDIN The Indonesian Wildlife Conservation Foundation, Jakarta, Indonesia

WANDA KUSWANDA Environmental and Forestry Research and Development Institute of Aek Nauli, North Sumatra, Indonesia

JITO SUGARDITO Center for Sustainable Energy and Resource Management, Universitas Nasional, Jakarta, Indonesia

This is an Open Access article, distributed under the terms of the Creative Commons Attribution licence CC BY 4.0.

\section{Primate Specialist Group ARRC Task Force}

In early 2020, the IUCN Species Survival Commission Primate Specialist Group officially launched the ARRC (Avoid, Reduce, Restore, Conserve) Task Force (arrctask force.org), to provide advice to companies and banks to Avoid ape habitat, Reduce impacts where avoidance is not possible, Restore habitats that have been negatively affected, and contribute positively to ape Conservation. Development projects such as mines and hydroelectric dams occur throughout ape habitat, and are a significant threat to their survival. The task force provides guidance on the distribution of apes and the location of priority areas, so that projects with the most significant anticipated impacts can be avoided. It also offers technical guidance to improve the practices of those projects that proceed, to reduce their impacts on apes. The task force is guided by a steering committee of 20 members, nine from ape range countries, and draws from the expertise of c. 150 ape experts. One major achievement of the task force was the inclusion, in the latest iteration of the Guidance Note to the International Finance Corporation (IFC) Performance Standard 6 (PS6; best practice lending standards for biodiversity), of a paragraph regarding projects operating in great ape habitat. As a result, companies seeking loans will need to engage with the task force to avoid great ape habitat and, where avoidance is not possible, develop appropriate mitigation measures.

The task force has advised c. 20 projects, leading to improvement in baseline surveys, increased avoidance of ape habitat, and improved practices, with better outcomes for apes. The task force will also review and monitor sensitive projects, will not be involved with projects where impacts to apes are deemed too significant to be mitigated, and will not engage with projects that directly or indirectly affect apes within World Heritage Sites. In addition to advising projects, lending banks and governments, the task force is also committed to strengthening capacity on these subjects 
within ape range countries. The Primate West Africa Team for Critical Habitat Protection programme was launched in April 2021, to help primatologists from West Africa advise and engage the private sector to minimize their impacts on primates.

GeNEVIEVE CAMPBelL (@ orcid.org/0000-0003-3356-0322)

Re:wild, Austin, USA. E-mail gcampbell@rewild.org

This is an Open Access article, distributed under the terms of the Creative Commons Attribution licence CC BY 4.0.

\section{Center for Species Survival Brazil}

To boost global conservation efforts, the IUCN Species Survival Commission (SSC) is promoting partnerships to establish Centers for Species Survival as part of the Reverse the Red movement (Oryx, 55, 1-2). Brazil is one of seven countries that has established a Center for Species Survival. The Center for Species Survival Brazil (Centro de Sobrevivência de Espécies), launched on 18 March 2021, is convened by Parque das Aves, IUCN and the SSC Conservation Planning Specialist Group and serves as a national hub to capitalize on the experience and tools of the IUCN network to help governments, NGOs and communities achieve their conservation goals.

The Center will build upon the existing structure of the Conservation Planning Specialist Group in Brazil and the strong presence of SSC Specialist Groups. This initiative will build capacity and dialogue with other national efforts, including public policies coordinated by the Chico Mendes Institute for Biodiversity Conservation such as national assessments of extinction risk and action plans. For example, Brazil has a national red listing infrastructure that aspires to converge with the IUCN Red List of Threatened Species. There are $>4,700$ Brazilian species of fauna that have been assessed nationally but are not yet on the IUCN Red List, and a recent comparison indicates a $37 \%$ category mismatch for the 1,426 endemic species that have been assessed both nationally and globally (Center for Species Survival Brazil, unpubl. data).

The launch of the Center for Species Survival Brazil was held virtually and transmitted live (youtube.com/watch?v= eGihADnLjoA\&t=9541s). Speakers covered diverse partnerships and tools, with 300 participants. The Center expects to work closely with IUCN and commission members, government agencies, universities, the zoo community and local people to ignite cooperation and optimism, exactly what we need to Reverse the Red.

FABIANA LOPES ROCHA (৫ orcid.org/0000-0003-0819-6290), EUGENIA CORDERO-SCHMIDT (৫ orcid.org/0000-0003-27190601) and RoSANA SUBIRÁ IUCN Species Survival Commission Center for Species Survival Brazil, Foz do Iguaçu, Brazil E-mail fabiana.rocha@csebrasil.org.br

Carmel CRoukamp (๑ orcid.org/0000-0002-1565-466X)

Parque das Aves, Foz do Iguaçu, Brazil

LEANDRO JERUSALINSKY (৫ orcid.org/0000-0003-0744-1987)

Centro Nacional de Pesquisa e Conservação de Primatas

Brasileiros, Instituto Chico Mendes de Conservação da Biodiversidade, Cabedelo, Brazil

SiLVIo MARCHINI (๑ orcid.org/0000-0002-8184-1631) Wildlife Conservation Research Unit, University of Oxford, Tubney, UK

KATIA FERRAZ (৫ orcid.org/0000-0002-7870-8696) Escola Superior de Agricultura Luiz de Queiroz, Universidade de São Paulo, Piracicaba, Brazil

Yara Barros Projeto Onças do Iguaçu, Foz do Iguaçu, Brazil

ARNAUD DESBIEZ (๑ orcid.org/0000-0001-5968-6025)

Instituto de Conservação de Animais Silvestres, Campo

Grande, Brazil

Nahomy De ANdRade IUCN Species Survival Commission, Caracas, Venezuela

ONNIE BYERS IUCN Species Survival Commission Conservation Planning Specialist Group, Apple Valley, USA

Jon PAUl RodRíguez (๑ orcid.org/0000-0001-5019-2870) IUCN Species Survival Commission, Provita, and Instituto Venezolano de Investigaciones Científicas, Caracas, Venezuela

This is an Open Access article, distributed under the terms of the Creative Commons Attribution licence CC BY 4.0. 